\title{
PERNILLE HOHNEN
}

\section{PENGEFORMER BLANDT FATTIGE FORBRUGERE I DANMARK}

Der er skrevet meget om forestillingerne om forbrugskultur, som de fremstår gennem reklamer, shoppingcentre, underholdningsparker og massemedier. Der er skrevet meget lidt om forbrugskultur som et økonomisk fænomen (Lodziak 2002:vii).

Hvad indebærer det at have meget begrænsede økonomiske ressourcer i et samfund som det danske, hvor velstand tages for givet, hvor betegnelser som politisk forbrug, livsstilsforbrug og frit valg dominerer, og hvor borgere i stigende grad betegnes som forbrugere tilhørende blå, grønne eller violette segmenter, alt afhængig af deres livsindstilling og identitet? Fattige familier har ofte svært ved at genkende sig selv i disse fremstillinger, fordi deres forbrugsmønstre har et andet sigte, rettet mod daglige fornødenheder og ofte fastlagt og planlagt til mindste detalje. Disse familiers forbrug er kendetegnet ved at få det til at løbe rundt dvs. at have penge nok til resten af måneden, at undgå at stifte gæld, og at kunne købe de dagligvarer, som opfattes som nødvendige. Kort sagt, at være fornuftige, at spare og ikke lade sig friste af unødvendige tilbud eller nemme løsninger som fx en middag på McDonald's eller fra den lokale grillbar. Samtidig handler forbrug blandt disse familier ikke så meget om valg som om kontrol både med de økonomiske ressourcer, med markedstilbud, med ønsker samt med egne og andres moralske forestillinger om det fornuftige kontra det ufornuftige. Fattige familiers forbrug står derfor i skærende kontrast til retorikken om det moderne forbrug som værende præget af øget valgfrihed med hensyn til både livsstil, identitet og politisk indflydelse for den enkelte (se bl.a. Bauman 1998, 1999; Bourdieu 1999; Hjort 2002).

Denne artikel analyserer økonomisk udsathed, og i særdeleshed hvordan forestillinger om penge og praksis vedrørende brugen af penge $\mathrm{i}$ fattige familier spiller sammen med den kvantitative pengemængde, der er til rådighed. Artiklen falder i to dele. Den første del præsenterer kritiske analyser af eksisterende forbrugsforskning, mens den anden del indeholder en empirisk analyse af pengeformer og forbrugsmønstre i fattige danske børnefamilier. Det at have meget få penge ser i en dansk sammenhæng ud til at resultere i bestemte forestillinger om penge og bestemte betalingsteknologier, der er afgørende forskellige fra de dominerende. Analysen af fattige familiers forbrugsmønstre peger således i retning af en mere overordnet social og kulturel differentiering af forbrugssamfundet i flere forbrugsregimer, der både konstrueres gennem forskelle i sociale udtryksformer som fx smag og stil og gennem en differentieret adgang til forbrugs- 
markeder og forbrugsteknologier og forskellige forestillinger om penge. Empirien vedrørende økonomisk sårbare danske børnefamiliers forbrugsmønstre udfordrer således en række dominerende forestillinger om sammenhængen mellem sociale og symbolske betydninger af penge og forbrug i vestlige kapitalistiske samfund, forestillinger der både indgår $i$ antropologisk og sociologisk forbrugsteori og mere generelle antropologiske studier af moderne penge.

\section{Antropologisk forbrugsforskning - et ikke-økonomisk felt}

Siden 1980'erne har der været stigende interesse for forbrugsstudier både inden for sociologien og inden for antropologien, og feltet er i høj grad blevet en etableret subdisciplin inden for begge fag. Der har dog i de seneste år fra flere sider været indvendinger og kritiske røster, der i forskellige sammenhænge har påtalt, at feltet er noget ensidigt, både i forhold til empirisk fokus og teori. Carrier og Heyman (1997) fremhæver således i artiklen „Consumption and Political Economy“ flere i deres øjne problematiske forhold, heraf særligt, hvordan det teoretiske perspektiv er domineret af en forestilling om objekter som symbolske markører, der analyseres inden for et lukket (geertziansk) betydningssystem:

I deres optagethed af objekter som symboler har antropologiske forskere forsømt, som Gell 1988 bemærker det, at placere symbolismen i det politisk-økonomiske processuelle og dynamiske felt, som man gennem den gamle produktionsbetonede analytiske ramme kæmpede hårdt for at fremhæve. Konsekvensen er, at disse analyser overser så meget, at hvis de skal repræsentere metamorfosen af antropologien, så er den antropologiske disciplin forarmet (Carrier \& Heyman 1997:356).

Carrier og Heymans kritik af forbrugsforskningen støttes i vid udstrækning af Löfgren (1996), som samtidig hæfter sig ved, at det empiriske fokus i forbrugsforskningen er meget snævert:

I undersökninger av konsumenter, tonåringer, hembyggere, och tevetittare känns det ibland som om man glider runt i en semiotisk skog av viskninger och rop, av meningar, innebörder, budskap [...] Vad vi möter i mycket av 1980- och 1990-talets kulturforskning är en ganska omedveten och gradvis insnävring av konsumtionsstudiet (Löfgren 1996:120).

Löfgren tilføjer, at der i konsumptionsforskningen er tendens til at fokusere på udvalgte befolkningsgrupper og deres forbrug af spektakulære forbrugsgoder, mens andre stort set ikke regnes med. Der er således et markant fokus på unge og deres „legen“ med identiteter gennem forbrug, mens det mere „hverdagsgrå“ og uheroiske forbrug af buskort, elektricitet, letmælk og køkkenrulle ikke har været en del af genstandsfeltet for forbrugsstudier (ibid.). Heller ikke studier af fattigdom og social deroute har haft forbrugsforskernes helt store interesse, og det er dobbelt uheldigt, da forbrugsmønstre og særligt normative forestillinger om det „,ndvendige“ og ,rationelle forbrug“ blandt kontanthjælpsmodtagere og flygtninge både i nutiden og set i et historisk perspektiv er en vigtigt politisk og ideologisk kampplads, hvor de rette og mest rationelle forbrugsmønstre fremhæves og det forkerte forbrug udstilles. Manglen på studier af fattigdom 
og forbrug, hverdagsforbrug samt den manglende hensyntagen til forbrugets moralske diskurser indebærer, at moralske og politiske betydninger af forbrug forbliver implicitte.

Den mest radikale kritik kommer dog ikke fra antropologernes egne række, men fra sociologen Conrad Lodziak (2002) i bogen The Myth of Consumerism. Lodziak kritiserer den dominerende forbrugsteori for at reproducere den økonomiske markedsretorik, særligt forestillingen om frit valg og forbrug som identitetsmæssig og social markør, samtidig med at den økonomiske dimension af forbrug slet ikke medtænkes.

I de sidste ti år eller deromkring har der udviklet sig en teoretisk konsensus angående forbrugsforskning inden for de akademiske discipliner kultursociologi og kulturstudier. Her portrætteres forbrugsområdet som en arena præget af valg og individuel frihed. Der fokuseres på forbrugets betydningsfulde aspekter og symbolværdien snarere end den materielle nytteværdi, og betydningen af forbrug, dets vedligeholdelse og artikulationen af selv-identitet og livsstil fremhæves (Lodziak 2002:1).

Også han mener, at forbrugerismen i alt for høj grad fokuserer på det ikke-materielle forbrug af billeder, symboler og mening, samt at både beskrivelsen af og forklaringen på forbrugsmønstre placeres i et snævert samspil mellem forbrugskulturen og den individuelle forbruger. Kommercielle interesser og markedsføring tillægges ikke nogen rolle, almen velstand tages for givet, og Lodziak ser derved i lighed med Chin, at ,forbrugsteorier oftest er baseret på ideen om, at forbrugere først og fremmest er fra middelklassen" (Chin 2001:11). Dette indebærer for det første en implicit forestilling om forbrugerens individuelle frie valg og for det andet, at der opstår forvirring vedrørende den økonomiske dimensions betydning, fordi symboler, fantasier og betydning jo ikke koster noget i sig selv. Man overser således, at forbruget af symboler ikke kan løsrives fra de økonomiske omkostninger, der er forbundet med købet af de varer og ydelser, som bærer de symbolske værdiformer og sociale distinktioner. Selvom deltagelsen i forbrugssamfundet forudsætter både penge at købe for, bestemte opfattelser af penge og bestemte omgangsformer med penge som betalingsmiddel, bliver forbrugskultur inden for den dominerende optik til et (positivt) meningsfuldt produkt af kreative, innovative forbrugere, samtidig med at forbruget bliver ,stedet, hvor vi bliver til dem, vi er, og vælger hvem vi gerne vil være. Jeg forbruger, derfor er jeg“" (Lodziak 2002:viii).

Lodziak fremfører, at særligt økonomisk dårligt stillede forbrugere har forbrugsvaner og måder at omgås penge på, der på afgørende områder bryder med dominerende forestillinger om forbrug, men at dette overses på grund af en grundlæggende ensrettet ideologisering af forbrugsteorien. Fattige familiers forbrug er kendetegnet ved en meget høj grad af kontrol og ved at være rettet mod opfyldelsen af basale fornødenheder såsom mad, tøj og bolig. Samtidig er disse familier ligesom alle andre eksponeret til dominerende forestillinger om velstand, om fri adgang til symbolske forbrugsformer og om betydningen af forbrug som social markør. Udfordringen er derfor at udvikle et begrebsapparat, der kan fastholde fokus på det materielle og samtidig tage højde for ændrede forestillinger om forbrugersamfundet og en tiltagende politisk konsensus om en udvikling, hvor „forbruger“ erstatter „,borger“. Samspillet mellem den kvalitative og den kvantitative fordeling af økonomiske og symbolske værdiformer bliver dermed helt central i konstruktionen af nye former for sociale differentieringsprocesser i forbrugssamfundet. 


\section{Økonomiske, sociale og moralske penge}

I en europæisk sammenhæng er det relativt sparsomt med antropologiske studier af penge, og endnu mere sparsomt med studier, der kombinerer kvalitativt forskellige opfattelser af penge og forbrugsformer med penge målt kvantitativt. En række antropologiske studier af overgangen til markedsøkonomi i Østeuropa og det tidligere Sovjetunionen har analyseret udviklingen af forskellige opfattelser af penge og nye sociale, økonomiske og symbolske grænser samt understreget den sociale betydning af symboliserede og abstrakte pengeformer (Hohnen 2003; Humphrey 1999; Sampson 1993; Verdery 1996). Selvom disse studier fremhæver samspillet mellem moralske, sociale og økonomiske betydninger af moderne penge for sociale marginaliseringsprocesser, ser det ikke ud til, at deres analyser har smittet af på studier af de „,gamle“ kapitalistiske økonomier i nævneværdigt omfang. Når Sampson (1993) finder, at de nyrige i Rumænien kæmper en ihærdig symbolsk kamp for moralsk og social anerkendelse af deres rigdom, hvilke paralleller ser vi så i vestlige kapitalistiske samfund? Hvilke moralske diskurser knyttes til brugen af penge i Danmark? Er det måske snarere omvendt sådan, at det er et større moralsk problem at være fattig end rig i samfund, hvor velstand antages at være tilgængelig? Er det flovt at være fattig? Hvad er den rigtige måde at forbruge på, når man er fattig?

Viviana Zelizer (1997) kommer i sin historiske analyse af pengeformer i USA, The Social Meaning of Money. Pin Money, Paychecks, Poor Relief, and Other Currencies, frem til, at folk også i vestlige økonomier udvikler alle mulige former for kvalitativt forskellige penge både $\mathrm{i}$ form af $\mathrm{fx}$ gavekort og særlige mønter, og mere vigtigt $\mathrm{i}$ form af øremærkning af helt almindelige penge. Det får hende til at efterspørge ,the missing link“" i den traditionelle pengeforskning:

Penge er hverken kulturelt neutrale eller socialt anonyme. De kan meget vel 'korrumpere' værdier og konvertere sociale relationer til antal, men værdier og sociale relationer kan omvendt også forandre penge gennem at give dem betydning og social markering (op.cit.:18).

Zelizer opstiller en analytisk ramme, hvor penge teoretiseres, så der tages højde for de kulturelle og sociale strukturer, der påvirker, begrænser og kontrollerer ,den flydende pengestrøm“, og hun er således involveret i at sammenkæde penges økonomiske, sociale og kulturelle betydning (ibid.). Som et led i denne teoretisering anvender hun begreberne „sociale valutaer“ og ,øremærkning“ af penge. Penge er i hendes optik ikke fri af sociale begrænsninger, men snarere socialt konstruerede ,valutaer“, knyttet til sociale omstændigheder og investeret med bestemte værdier og normer, særligt hvor den sociale interaktion er præget af bestemte interesser. Det kan være i form af at etablere eller opløse bestemte sociale relationer (fx gennem betaling af børnepenge og hustrubidrag), kontrollere andre ( $f x$ gennem bestikkelse) eller etablere eller fastholde bestemte former for social ulighed $\mathrm{i}$ form af patron-klient-relationer ( $\mathrm{fx}$ gennem sociale ydelser eller velgørenhed). Det skal bemærkes, at der ofte foregår en „kamp“ mellem udvekslingspartnerne både om indholdet og kontrollen med øremærkningen. Helt konkret opregner Zelizer en række forskellige teknikker til øremærkning af penge: 
Såsom begrænse brugen af penge, regulere former for tildeling af penge, opfinde ritualer for præsentationen af penge, ændre på penges fysiske fremtræden, designe bestemte fysiske rum for bestemte penge, sammenkæde bestemte betydninger med bestemte beløb, tildele ordentlige brugere bestemte penge og øremærke bestemte ydelser til bestemte formål (Zelizer 1997:29).

I det følgende vil jeg med udgangspunkt i Zelizers analytiske ramme vedrørende måder at øremærke penge på i sociale valutaer samt kritikken af den manglende økonomiske dimension i forbrugsforskningen analysere forholdet mellem kvalitativ og kvantitativ værdifastsættelse i fattige danske børnefamilier. Erfaringerne med den kvalitative mærkning af penge i disse familier udfordrer samtidig både gældende forestillinger om udbredelsen af „,forbrugssamfundet" og teoretiske forestillinger om sammenhængen mellem økonomiske og sociale værdier i kapitalistiske samfund.

\section{Pengeformer og moderne fattigdom i Danmark}

Hvad betyder indtægtens størrelse for adgangen til forskellige forbrugsformer og forskellige måder at tænke og mærke penge på? Hvordan tælles penge blandt fattige familier? Og hvad fortæller særlige former for mærkning af ,fattige folks penge“ om forbrug og forbrugsregimer i en dansk sammenhæng? I det følgende diskuteres disse spørgsmål med udgangspunkt i en række empiriske eksempler vedrørende øremærkning af penge og forbrugsmønstre blandt børnefamilier med meget begrænsede økonomiske ressourcer fra et udvalgt lokalområde i nærheden af København. ${ }^{1}$

\section{Fastlagt, forudbestemt og kontrolleret}

Forbruget blandt de økonomisk udsatte børnefamilier er karakteriseret ved fastlagthed og forudbestemthed. Der skrives lister, laves budgetter og læses tilbudsaviser fra lavprismarkeder og discountforretninger i lokalområdet. Den altafgørende motivation bag forbruget er dels at få indtægten til at strække til næste indtægt, dels at opfylde de materielle behov for familien, særligt i form af tøj og måltider til hele måneden. Penge i disse familier er opdelt efter behovsforbrug og tælles i poster som: husleje og faste udgifter, et par sandaler, 30 gange aftensmad, mælk, brød og togbilletter. De fleste af forældrene $\mathrm{i}$ disse familier ved præcis, hvor mange penge de har til rådighed, samt hvad disse penge skal bruges til. I forlængelse af Zelizer ovenfor kan man anføre, at stort set alle penge i disse familier er øremærkede til bestemte formål, allerede inden de udbetales:

Så er prioriteringen, at der er mad og wc-papir og tandpasta og shampoo og alle de der ting. Det handler vi godt ind først på måneden, hvis det mangler, så der er til hele måneden. $\mathrm{Og}$ så prøve at have fyldt fryseren og sådan, så der er mad til hele måneden. Altså, vi står da heldigvis ikke og mangler, det synes jeg ikke. Vi står ikke der med 5 kr. eller noget, det synes jeg ikke, vi gør. Nej, vi kan få det til at løbe rundt, men jeg vil nok sige, der er ikke det store overskud. Det er der ikke...

(Anne, enlig mor til hjemmeboende datter og to voksne børn) 
Egentlig ville jeg helst have sådan et skilt med 'Nej tak til reklamer' på min dør. Men det har jeg ikke, for jeg er nødt til at kunne kigge i de der tilbud. Jeg plejer at købe fx kylling, det går godt her. Så finder jeg ud af, hvor der er tilbud, fx i går i Kvickly, der var et eller andet fødselsdagstilbud, hvor $2 \mathrm{~kg}$ kyllingelår kostede $15 \mathrm{kr}$. Det er billigt, så der drønede jeg op og købte tre poser. Når der er nogle gode tilbud i starten af måneden, så gælder det om at få fyldt fryseren op og så kigge på, hvor mange dage der er til. Så kan man sige, at der er mad til resten af måneden, så skal der bare lige købes ...

(Berit, enlig mor til to hjemmeboende drenge og en voksen datter)

Begrænsede økonomiske ressourcer anvendes omhyggeligt, og der udvikles gennemgående forskellige strategier rettet mod at kontrollere forbruget. Samtidig peger disse strategier i retning af nogle bestemte forestillinger om sammenhængen mellem pengenes form på den ene side og forbruget af dem målt kvantitativt på den anden.

Én type af sådanne strategier foregår i forbindelse med selve indkøbet af varer, som søges kontrolleret gennem at afsætte et bestemt beløb, gennem at anvende bestemte indkøbstaktikker, $\mathrm{fx}$ at skynde sig gennem forretningen eller gennem at reducere antallet af besøg i forretningen:

Altså, nogle gange laver jeg lister, men hvis jeg kun skal have fire ting, så skynder jeg mig kun lige at tage $100 \mathrm{kr}$. i lommen, og så løber jeg bare ind og tager, hvad jeg skal have, for ellers bruger jeg alt for mange penge.

(Dorthe, enlig mor til tre drenge og to piger, der alle bor hjemme)

Jeg handler som regel ind til en måned ad gangen. Så kan det godt være, der mangler lidt kød og mælk og brød og sådan noget. Men normalt så sætter jeg mig ned og laver en seddel, når jeg får penge. Så går jeg ud og handler stort ind af alt det, jeg mangler, alt det, hvad skal man sige, af de tunge ting. Fordi jeg har det sådan, at hvis jeg går op $\mathrm{i}$ Netto efter to ting, så kommer jeg hjem med ti.

(Jane, mor til en dreng og en pige, der begge bor hjemme)

Disse „,begrænsningsstrategier“, som også indebærer at bruge taletidskort og ikke abonnement til mobiltelefonen, udgør én form for mærkning af penge i form af en helt konkret afgrænsning af ,det beløb, der anvendes til et givet formål“. Denne måde at afgrænse og opdele penge på ses også i mere principiel form, ved at ingen af de fattige familier havde dankort. Det var ikke nødvendigvis, fordi de ikke kan få det (selvom nogle familier på kontanthjælp og familier med stor gæld ikke har mulighed for at få nogen form for kreditkort), men fordi de ikke ville have det:

Jeg vil ikke have dankort, for så bruger jeg alt for mange penge.

(Dorthe, enlig mor til fem små børn)

Jeg vil hellere have pengene i hånden, så jeg kan føle, hvad det er, jeg har af penge, og så jeg ved, at nu har jeg brugt dem, nu er det dét. Jeg ved ikke, om dankort ville være for fristende for mig - det tør jeg så bare ikke - at kunne hæve $100 \mathrm{kr}$. ekstra, om det ville være for fristende, fordi så tager det pludselig overhånd.

(Anne, enlig mor til hjemmeboende pige og to voksne børn)

Sådan noget som dankort vil jeg ikke have. Jeg vil vide, hvad jeg har og bruger af penge. Sådan er jeg nemlig.

(Lise, mor til to hjemmeboende drenge) 
Så længe jeg er på kontanthjælp, vil jeg hellere have pengene i hånden, så jeg gerne skulle kunne betale for det, jeg får.

(Jane, mor til en dreng og en pige, der begge bor hjemme)

For disse familier er der en klar forskel på dankortpenge og papirpenge. Papirpenge kan man have $\mathrm{i}$ hånden, man kan $\mathrm{i}$ bogstavelig forstand føle, om de er der, hvor mange der er, og føle, når de er brugt. Man kan mærke dem til bestemte formål og derved afgrænse og begrænse brugen af dem. Anderledes forholder det sig med elektroniske penge. Forestillingerne om elektroniske penge handler ikke kun om, at man er bange for at komme til at bruge lidt for mange penge, men snarere om at være bange for fuldstændig at miste kontrollen ved at åbne for en strøm af umærkede og dermed ukontrollable penge. Her skal det påpeges, at også Zelizer (1997) skiller elektroniske penge fra papirpenge, og hun konkluderer, at de elektroniske penge i højere grad end papirpengene ligner økonomernes idealforestilling om neutrale, delelige og udelukkende kvantitative penge, som er svære at mærke kvalitativt. Når mennesker med meget få penge er bange for de elektroniske penge, hænger det derfor øjensynlig sammen med, at disse er vældig svære at mærke som kvalitativt forskellige og kvalitativt signifikante beløb rettet mod bestemte behov og afsat til bestemte udgifter. Derved bliver de langt vanskeligere at kontrollere, man mister overblikket og mulighederne for at prioritere.

\section{Cyklisk værdisætning}

Ud over kategorisering af penge i forhold til indtægtskilde og forbrugsbehov afhænger vurderingen af penges værdi også af, hvornår i måneden, man ,måler“. Penge har ikke den samme værdi i starten af måneden som i slutningen:

Det er sådan, at først på måneden, der lever vi sådan nogenlunde normalt, ligesom andre gør ... også med junkfood eller cola ind imellem. Der frådser vi måske lidt, men når vi så når til den sidste del af måneden, så er det måske, at vi ikke har råd til speltmel, og så er det, at V han må spise rugbrød. Nogle gange, hvis han vil have et eller andet, så siger jeg: 'Du må godt få den ting, men så må du spise rugbrød resten af måneden.' 'Ja, ja', siger han, og det har han ikke noget imod. I slutningen af måneden er han ikke kræsen, og han kan sige: 'Næh, hvad har du lavet til aftensmad?' Og så ligger der noget, der er lavet på en sten.

(Berit, enlig mor til to hjemmeboende drenge og en voksen datter)

Ovenstående citat viser ikke alene, hvordan økonomien tilpasses en „månedscyklus“, men hvordan selv smagsløgene påvirkes af, hvor i måneden vi befinder os. Næsten alle de interviewede familier betoner denne dimension af deres forbrug, hvor man ,altså ikke køber sko i slutningen af måneden, vel!“‘

Men også andre indtægter, særligt børnefamilieydelse og børnebidrag påvirker udformningen af den cykliske økonomi:

Kontanthjælpen er på 10.000 et eller andet, og så kommer skattefar, og så er jeg er nede $i$ at få 7.100 udbetalt. Det, jeg kan sige, er, at det, jeg har til os om måneden, det er faktisk boligsikringen, for der er ikke ret meget tilbage af de andre. Så har jeg en budgetkonto, de penge trækker banken fra mine børnepenge, som kommer på forskellige 
tidspunkter i måneden. Jeg får procenttillæg, og jeg ved, at Josephines penge kommer den 28., den 4. kommer Amalies, og den 1. kommer Lasses.

(Helle, enlig mor til fire hjemmeboende børn)

Børnepengene tænkes her ikke i beløb, men i de datoer de ankommer, og der kalkuleres derfor i meget høj grad med tidsligheden i indtægter. Dette indebærer ikke, at disse kvinder ikke ved, hvor mange penge de får, for det ved de udmærket, men timingen er en vigtig del af forestillingen om pengenes værdi. Dette ses særlig tydelig i nedenstående citat, hvor en kvinde forsøger at slippe af med sin store gæld ved at lave faste aftaler med kreditorerne om nogle faste og for hende meget store afdrag hver måned. Hun kan ikke overskue at skulle betale af på det sidste af de lån, hun har, hver den første sammen med de øvrige afdrag og foreslår i stedet kreditorerne, at dette lån trækkes delvist af børnebidraget, som hun modtager fra faren d. 20. i hver måned, dels af børnefamilieydelsen, som hun modtager hver tredje måned:

På nuværende tidspunkt slås jeg med det ene af de her lån, så hver gang jeg får de her penge d. 20., så kører de ind på den regning, for ellers kan jeg ikke få det til at hænge sammen, og så er der de penge, jeg får hver tredje måned. Det er fordi, hvis jeg også skulle lade den regning betales [af den månedlige indkomst, $\mathrm{PH}$ ], så kunne jeg slet ikke overskue det, for så var der slet ingen penge tilbage. Så var det, jeg tænkte på: Hvis jeg prøver at snakke med dem om at lave en ordning, hvor de får et beløb hver d. 20. eller hver tredje måned. Det godtog de jo så.

(Anne, enlig mor med hjemmeboende datter og to voksne børn)

Pointen her er, at penge ikke kun udregnes på basis af hvor mange, men på basis af hvilke penge der skal bruges til at betale det pågældende lån med. Selvom man ud fra en kvantitativ beregning øjensynlig kunne regne sig frem til et gennemsnitsbeløb, der kunne betales månedligt, og dvs. et kvantitativt set tilsvarende beløb til det, der betales af de her penge d. 20. og hver tredje måned, så er det ikke sådan, pågældende informant tænker, og for hende er det ikke det samme. Det er for uoverskueligt, hvis lånet skal betales af den månedlige indtægt, og det må tages af nogle andre penge. Udregningen af betalingsevne handler her ikke kun om beløbets størrelse, men også i høj grad af, hvilke penge der anvendes, samt hvornår på måneden der skal betales.

\section{Personrelateret værdisætning}

Endeligt skal det understreges, at vurderingen af pengenes værdi i familierne med begrænsede ressourcer i høj grad afhænger af, hvem de bruges på. I alle de interviewede familier havde børnenes forbrug højeste prioritet, ofte på bekostning af tøj og andre ret basale nødvendigheder som tandlæge og medicin til mor. Forskellene er så store og peger på en så ulige fordeling af ressourcer inden for familien, at der sættes spørgsmålstegn ved gældende forestillinger om et fælles indkomstniveau for et hushold. Denne skæve fordeling svarer i øvrigt til, hvad den belgiske sociolog Kochuyt (2004) mener, man kan kalde skabelsen af „kunstig fattigdom“ for forældrene samtidig med „kunstig velstand" for børnene inden for én og samme familie. ${ }^{2}$

Indtægter og udgifter i familier med små indtægter mærkes altså efter forskellige principper, som ser ud til at have stor betydning for oplevelsen af økonomiens 
bæredygtighed. Herudover spiller den økonomiske dimension af penge også sammen med moralske forestillinger om, hvad der er „,det rigtige“ at bruge pengene til.

\section{Fra økonomiske til moralske dilemmaer}

I familier med få penge er forbrugsmønstret kendetegnet ved, at der i princippet ikke er nogen frie penge til rådighed. Mange er samtidig afhængige af sociale ydelser i form af kontanthjælp, førtidspension eller andre former for overførselsindkomster, og for en dels vedkommende består husstanden af én forælder (som regel en kvinde) og børn. Blandt denne gruppe er der endvidere tendens til, at penge og valg vedrørende forbrug domineres af moralske diskurser, og der sker nærmest en slags migration af økonomiske problemstillinger til det moralske felt for forældrene i disse familier. ${ }^{3} \mathrm{De}$ fleste moralske dilemmaer handler om prioritering af det fornuftige forbrug, dvs. indkøb af mad, tøj og andre basale fornødenheder, i forhold til hvad man kunne kalde „det ekstra og ønskelige“, bl.a. forlystelser, mærkevarer m.m.; aktiviteter eller varer, der i samfundet som helhed opfattes som normale. Det nødvendige opfattes på én gang som det rigtige og som urimeligt skrabet i forhold til det ønskelige, som ses som illegitimt „for os med få penge“", samtidig med at det egentlig opfattes som rimeligt. Familiernes oplevelse af deres økonomi er således, at selvom de prioriterer basale fornødenheder, og de samtidig opfatter dette som den mest rimelige måde at bruge pengene på, opleves denne prioriteringen af det fornuftige alligevel ikke som acceptabel.

Jeg vil gerne give børnene noget andet og noget mere. Nogle gange synes jeg, det er lidt skrabet, når man kigger i skufferne. Jeg ville godt give dem noget mere. Men det er der ikke mulighed for. En gang imellem tænker man da, det er da også synd for dem. De burde kunne få noget af det, andre børn får.

Jeg kunne godt tænke mig at gå i biografen ... nogle rimelige ting, som egentlig for mig måske er ufornuftige. Det skal der også være plads til, så mine børn kan komme og sige: I dag har jeg oplevet noget.

(Jane, mor til en dreng og en pige, der begge bor hjemme)

Derved opstår der ofte dilemmaer vedrørende prioriteringen af familiens ressourcer, som på den ene side bør gå til mad og husleje, men som på den anden side også bør give særligt børnene mulighed for social deltagelse i lighed med deres kammerater. Dette fører til vanskelige overvejelser, hvor det rigtige valg nærmest ikke er til stede:

Altså, vi kan jo ikke gøre det ... for vi skal bruge de penge, vi har ... Men vi har gjort det, selvom vi skulle bruge pengene - jeg kunne ikke bære at sige 'Nej vi har ikke råd til det'. Så vi har lige været i Tivoli og brugt mange penge... Og nu: Hvad skal vi spise?

(Nadia, mor til to små børn)

Beslutningerne vedrørende brugen af penge kommer her til at handle om følelser og moralske overvejelser $\mathrm{i}$ forbindelse med at forsøge at operere mellem forestillingerne om det forkerte forbrug og det rette forbrug, samtidig med at der ikke findes nogen løsning, der på én gang er moralsk og økonomisk acceptabel. Valgfriheden begrænser sig her til et valg mellem det fornuftige, men urimelige og det ufornuftige og rimelige. Der er altså her i meget høj grad tale om en udbredt øremærkning af midler til bestemte 
forbrugsformer, samtidig med at der ikke rigtig findes et forbrugsmønster, der er både økonomisk og moralsk acceptabelt. De forkerte penge bruges derfor ofte til det forkerte forbrug, forstået på den måde, at penge, der er bundet til køb af basale fornødenheder, anvendes til ting eller aktiviteter, der ikke er basale fornødenheder, men som alligevel opleves som socialt nødvendige. Derved ender de økonomiske dispositioner ofte som moralske problemstillinger forbundet med skyld og skam.

\section{Konklusion}

Set i lyset af den danske empiri er kritikken af forbrugsforskningens manglende hensyntagen til økonomisk ulighed og adgang til penge meget rammende. Økonomiske overvejelser fylder vældig meget for familier med få penge. Pointen er dog samtidig, at begrænsede økonomiske ressourcer ikke alene har betydning i traditionel økonomisk forstand. Empirien peger snarere i retning af, at begrænsede penge i kvantitativ forstand fordrer, hvad Zelizer betegner som en udbredt kvalitativ „øremærkning“ og opdeling af de penge, man har, i bestemte ,sociale valutaer" beregnet til bestemte fastlagte formål. Denne øremærkning omhandler opdelingen af de penge, man har, efter forskellige formål, hvor særligt børnenes behov tilgodeses. Derudover anvendes øremærkning til at begrænse pengeforbruget ved fx kun at tage et vist beløb med, når man går ned for at handle. Samtidig gælder det, at både pengenes værdi og øremærkningen af dem ændrer sig i forhold til tidspunktet på måneden. I det omfang frie penge overhovedet kan findes, så sker det i begyndelsen af måneden og ikke i slutningen. Endelig ser det ud til, at mærkningen i sig selv udgør en moralsk kampplads for de fattige familier i form af oplevelsen af konflikter og modstridende opfattelser af både egne og andres ideer om den korrekte øremærkning. Fattige familiers forbrug er eksponent for familiens moralske status samtidig med, at det er meget vanskeligt (af og til umuligt) at fordele de økonomiske midler, man har på en i både egne og andres øjne legitim måde. Hvor de dominerende forestillinger om forbrugssamfundet $i$ samfundet som helhed er præget af ideer om valgfrihed, mobilitet og abstrakte og symbolske pengeformer, ser det ud til, at selve basis for kalkulationen af økonomisk værdi i de fattige familier er baseret på helt andre principper.

Det at have meget få penge har dermed ikke alene betydning for, hvor meget man kan købe, men også for forestillingen om økonomisk værdi, social status og moralsk legitimitet. Der er således et tæt samspil mellem kvantitative og kvalitative penge $i$ familier med begrænsede økonomiske ressourcer. Dette indebærer ikke, at pengenes kvalitative dimension slet ikke findes blandt familier med flere penge til rådighed, jf. Zelizers pointe ovenfor om, at penge altid til en vis grad har en kvalitativ dimension, men snarere at samspillet mellem de kvalitative og kvantitative dimensioner har en særlig betydning for fattige familiers beregning af deres økonomiske, sociale og moralske råderum. I fattige familier er pengene få $o g$ fastlagte $o g$ forudbestemte, og familiens oplevelse af deres samlede økonomi baseres på en kombination af disse dimensioner. Samtidig opleves mærkningen af pengene i forhold til familiens ønsker og behov ambivalent. Man oplever at være tvunget til at målrette anvendelsen af sine penge til bestemte formål, samtidig med at man ikke oplever disse formål som rimelige eller legitime. 
Økonomisk sårbarhed og fattigdom opleves derfor i disse familier ikke alene som en effekt af det at have for få penge, men knyttes også til oplevelsen af nærmest altid at have den forkerte slags. Dette skal forstås på den måde, at når pengene er øremærket til basale nødvendigheder, primært mad og tøj, er der ikke penge til andre ting, fx en tur i Tivoli, selvom denne alternative anvendelse opleves som nødvendig af andre grunde, fx børnenes sociale trivsel. Når pengene overhovedet mærkes til bestemte formål er det bl.a. et forsøg på at kontrollere brugen af dem ved at sikre, at der er tilstrækkeligt med penge til, at der er mad, tøj osv. måneden ud. Men denne logik og rationalitet for „det fornuftige forbrug“ indebærer også, at der ingen frie penge er, og dermed betones den kvalitative dimension i særlig grad blandt fattige familier. Konsekvensen af denne mærkning, der på én gang er nødvendig og begrænsende, er, at andre måder at bruge pengene på end de på forhånd fastlagte opleves som illegitime. Den økonomiske udsathed resulterer dermed i alvorlige følelsesmæssige og moralske dilemmaer. Samtidig er det ikke overraskende meget problematisk at operere med en sådan økonomi i et samfund, hvor den dominerende diskurs tilsiger, at vi lever i et forbrugssamfund, hvor vi til en vis grad vælger identitet, livsstil og social status gennem forbrugsvalg. Fattige familier har ikke adgang til sådanne valg, hverken de konkrete valg eller symboliserede former. Har man ikke dankort, er det tidskrævende og besværligt at få adgang til sine papirpenge, når der bliver længere mellem bankfilialerne, samtidig med at man ikke får adgang til abstrakte forestillinger om penge, relateret til elektroniske betalingsmidler, som i stigende grad bliver det normale i resten af samfundet. Både symbolsk og konkret skabes derved et afgrænset og adskilt (og lokalt) forbrugsfelt for disse forbrugere, hvor mulighederne for at vælge er så begrænsede, at det rette valg ikke findes, samtidig med at det forkerte valg opleves som ens egen skyld. Der er således langt mere på spil end blot forbrugsvalg.

\title{
Noter
}

1. De fleste af de interviewede familier har så lave indtægter, at de har kunnet få fondsmidler til at fă finansieret en uges sommerferie i Danmark. Empirien udgøres hovedsageligt af 17 semi-strukturerede interview med mødre og enkelte par, deltagelse $\mathrm{i}$ beboermøder og diskussioner vedrørende butikslivet og fritidslivet $\mathrm{i}$ området samt deltagerobservation i begrænset omfang i og omkring butikker og skoler. Alle interviewede optræder i teksten under pseudonym.

2. For en uddybende gennemgang af fordelingen af ressourcerne inden for familien, se Hohnen (2004)

3. Det skal bemærkes, at sådanne moralske overvejelser i det store hele var fraværende hos de otte familier med højere indkomster, som vi også talte med.

\section{Litteratur}

\author{
Bauman, Zygmunt \\ 1998 Work, Consumerism and the New Poor. Buckingham: Open University Press. \\ 1999 In Search of Politics. Oxford: Polity Press. \\ Bourdieu, Pierre \\ 1999 The Weight of the World: Social Suffering in Contemporary Society. Oxford: Polity Press.
}


Carrier, James \& Josiah Heyman

1997 Consumption and Political Economy. The Journal of Royal Anthropological Institute $3(2): 355-73$.

Chin, Elizabeth

2001 Purchasing Power: Black Kids and American Consumer Culture. Minneapolis: University of Minnesota Press.

Hjort, Torbjørn

2002

Konsumptionsvilkår för hushåll med kanpp ekonomi. Et svagt utvecklat kunskapsfelt.

Socialforskningsinstituttet, Arbejdspapir 1:2

Hohnen, Pernille

2003 A Market out of Place? Remaking Economic, Social and Symbolic Boundaries in post-

Communist Lithuania. Oxford: Oxford University Press.

2004 "I Wish I didn't Always Have to Say No.” Paper præsenteret på ESA (European Sociology Association), København 26.-28. august.

Humphrey, Caroline

1999 Traders, "Disorder”, and Citizenship Regimes in Provincial Russia. I: M. Burawaoy \& K.

Verdery (eds.): Uncertain Transition: Ethnographies of Change in the Postsocialist World.

Oxford: Rowman \& Littlefield Publishers, Inc.

Kochuyt, T.

2004 Giving Away One's Poverty: On the Consumption of Scarce Resources within the Family. The Sociological Review 52(2):139-61.

Lodziak, Conrad

2002 The Myth of Consumerism. London: Pluto Press.

Löfgren, Orvar

1996 Konsumption som vardaglig praktik och ideologiskt slagfält. Socialventenskaplig tidskrift 12:116-27.

Sampson, Steven

1993 Money without Culture, Culture without Money: Eastern Europe's Nouveaux Riches.

American Journal of European Cultures 3(1):7-31.

Verdery, Katherine

1996 What was Socialism and What Comes Next? Princeton: Princeton University Press.

Zelizer, Viviana

1997 The Social Meaning of Money: Pin Money, Paychecks, Poor Relief, and Other Currencies. Princeton: Princeton University Press. 